\title{
Non-invasive molecular imaging of inflammatory macrophages in allograft rejection
}

\author{
Alexander S. G. O'Neill ${ }^{1,2 *}$, Samantha Y. A. Terry', Kathryn Brown ${ }^{3}$, Lucy Meader ${ }^{3}$, Andrew M. S. Wong ${ }^{4}$, \\ Jonathan D. Cooper ${ }^{4}$, Paul R. Crocker ${ }^{5}$, Wilson Wong ${ }^{3}$ and Gregory E. D. Mullen ${ }^{1,3}$
}

\begin{abstract}
Background: Macrophages represent a critical cell type in host defense, development and homeostasis. The ability to image non-invasively pro-inflammatory macrophage infiltrate into a transplanted organ may provide an additional tool for the monitoring of the immune response of the recipient against the donor graft. We therefore decided to image in vivo sialoadhesin (Sn, Siglec 1 or CD169) using anti-Sn mAb (SER-4) directly radiolabelled with ${ }^{99 \mathrm{~m}} \mathrm{Tc}$ pertechnetate.

Methods: We used a heterotopic heart transplantation model where allogeneic or syngeneic heart grafts were transplanted into the abdomen of recipients. In vivo nanosingle-photon emission computed tomography (SPECT/CT) imaging was performed 7 days post transplantation followed by biodistribution and histology.

Results: In wild-type mice, the majority of ${ }^{99 m}$ Tc-SER-4 monoclonal antibody cleared from the blood with a half-life of 167 min and was located predominantly on $\mathrm{Sn}^{+}$tissues in the spleen, liver and bone marrow. The biodistribution in the transplantation experiments confirmed data derived from the non-invasive SPECT/CT images, with significantly higher levels of ${ }^{99 \mathrm{~m}}$ Tc-SER-4 observed in allogeneic grafts $(9.4( \pm 2.7) \% \mathrm{ID} / \mathrm{g})$ compared to syngeneic grafts $(4.3( \pm 10.3) \% \mathrm{ID} / \mathrm{g})$ $(p=0.0022)$ or in mice which received allogeneic grafts injected with ${ }^{99 \mathrm{~m}} \mathrm{Tc}-\mathrm{lgG}$ isotype control $(5.9( \pm 0.6) \% \mathrm{ID} / \mathrm{g})$ $(p=0.0185)$. The transplanted heart to blood ratio was also significantly higher in recipients with allogeneic grafts receiving ${ }^{99 \mathrm{~m}} \mathrm{Tc}$-SER-4 as compared to recipients with syngeneic grafts $(p=0.000004)$ or recipients with allogeneic grafts receiving ${ }^{99 \mathrm{~m}} \mathrm{Tc}-\mathrm{lgG}$ isotype $(p=0.000002)$.
\end{abstract}

Conclusions: Here, we demonstrate that imaging of $\mathrm{Sn}^{+}$macrophages in inflammation may provide an important additional and non-invasive tool for the monitoring of the pathophysiology of cellular immunity in a transplant model.

Keywords: Macrophages, Cardiac transplantation, Preclinical imaging, Sialoadhesin, SER-4

\section{Background}

Macrophages are tissue-resident components of the innate and adaptive immune systems and perform a variety of functions in host defense and maintenance of homeostasis [1]. As such, they are crucial in the progress and resolution of a variety of pathological conditions, including cancer, autoimmunity, atherosclerosis and rejection of transplanted organs [2]. There are a variety of antigens used in the

\footnotetext{
* Correspondence: alexander.oneill@hmc.ox.ac.uk

'Department of Imaging Chemistry and Biology, Division of Imaging Sciences and Biomedical Engineering, King's College London, St. Thomas' Hospital, London SE1 7EH, UK

${ }^{2}$ Division of Medical Sciences, University of Oxford, John Radcliffe Hospital, Oxford OX3 9DU, UK

Full list of author information is available at the end of the article
}

ex vivo identification of human macrophages, and of these, the markers CD64, CD68 (Macrosialin), CD163, CD169 (sialoadhesin) and CD204 (macrophage scavenger receptor A) represent the set of trans-species pan-macrophage markers [3]. Due to the significant plasticity of macrophage phenotype, producing a single macrophage marker has eluded researchers and none is uniquely expressed on macrophages. CD64 is expressed on monocytes and subsets of germinal and blood dendritic cells, CD68 on various leukocytes, CD163 on monocytes, CD204 on monocytes and dendritic cells, and of the most myeloid restricted of these (CD163) significant amounts are found as soluble product [4], complicating its use for in vivo non-invasive imaging.

\section{实 Springer}


To date, the majority of macrophage imaging has been performed by magnetic resonance imaging (MRI) using non-specific nanoparticles such as superparamagnetic iron oxide (SPIO). SPIOs were injected intravenously (i.v.) and taken up in vivo by phagocytic cells [5]. This uptake is not unique to macrophages and cells such as dendritic cells can also take up iron oxide particles [6]. Other approaches have involved ex vivo non-specific labelling of macrophages with a contrast agent, such as a nanoparticle or a radiolabel, followed by MRI or single-photon emission computed tomography imaging (SPECT) imaging [7]. Recently, the targeting of macrophages with labelled antibodies has begun to be explored, with a number of groups reporting success with this technology in preclinical models. ${ }^{111}$ In-labelled anti-F4/80-A3-1 [8], ${ }^{68}$ Ga-labelled CD163 [9] and optically labelled CD206 [10] have shown the feasibility and utility of macrophage targeting in vivo. In addition, radiotracers targeting translocator protein (TSPO) as a biomarker of microglial activation and macrophage infiltration in the brain have been used [11].

Here, we report non-invasive in vivo imaging specific for inflammatory macrophages using the anti-sialoadhesin (Sn, Siglec 1 or CD169) monoclonal antibody, SER-4 [12]. Increasing attention is being paid towards the marker Sn $[13,14]$, which under quiescent conditions is expressed on subsets of macrophages in secondary lymphoid tissues, such as the lymph nodes and spleen [12]. However, $\mathrm{Sn}^{+}$ macrophages can also be found in a variety of pathological conditions [15-17]. $\mathrm{Sn}^{+}$macrophages not only exhibit classic innate immune cell behaviour by acting as professional phagocytes but also display a close relation in promoting immune responses [18] through the activation of other immune effector cells including CD8 T cells [19], B cells [20] and iNKT cells [21]. This relationship is demonstrated by enhanced immunity resulting from the targeting of antigenic material to $\mathrm{Sn}^{+}$macrophages $[22,23]$ and also by the amelioration of autoimmunity following Sn knockdown [24-26]. Increasingly, Sn expression is being linked clinically with disease progression in a variety of settings and is finding use as a marker of inflammation [27].

There is still a clinical necessity for further development of non-invasive imaging biomarkers not only for the diagnosis and staging of disease but also for interim assessment of therapies. Solid organ transplantation is one area where the development of a non-invasive imaging biomarker would aid therapy response assessment. The incidence of acute transplant rejection within the first year has decreased dramatically by the introduction of modern immunosuppressive therapies, while the rates of chronic transplant rejection have remained high [28]. While efforts are underway for the non-invasive imaging of ischemia reperfusion injury post transplantation [29], not much has been done in the way of non-invasive imaging of recipient macrophages in graft rejection. Thus, close surveillance of transplanted organs remains imperative. The current clinical standard of repetitive invasive endomyocardial biopsies is prone to sampling error, entails a risk of severe complications, causes discomfort and anxiety for the patients and, unlike for kidney transplants, is usually performed as a last resort. Therefore, developing non-invasive yet quantitative diagnostic tools for the monitoring of allograft rejection would fulfil an unmet clinical need.

The aim of this study is to test the biodistribution of ${ }^{99 \mathrm{~m}}$ Tc-SER-4 in normal animals and an inflammatory model such as an acute rejection model.

\section{Methods}

\section{Mice, culture media, reagents and antibodies}

C57BL/6 (H-2b) and BALB/c (H-2d) mice were ordered from Harlan Olac (Bicester, UK). Sn knockout $\left(\mathrm{Sn}^{-/}\right)$mice were bred and maintained in the Biological Services Unit at King's College London. RPMI 1640 medium (Sigma, Poole, UK), supplemented with $5 \mathrm{mM}$ L-Glut (Invitrogen, Paisley, UK), $100 \mathrm{U} / \mathrm{mL}$ penicillin (Invitrogen), $100 \mu \mathrm{g} / \mathrm{mL}$ streptomycin (Invitrogen), 10 \% IgG-depleted foetal calf serum (Source Bioscience UK Ltd., Nottingham, UK), $1 \mathrm{mM}$ Hepes (Invitrogen) and $0.05 \mathrm{mM}$ mercaptoethanol (Invitrogen), was used for antibody production, labelling and in vitro binding assays. Antibodies were purified using 5 mL HiTrap Protein G HP and 13.5 mL G-25 Sephadex desalting columns (PD-10) (GE Healthcare, Chalfont St. Giles, UK). Size exclusion chromatography (SEC) was performed using an Agilent 1200 series (Agilent, Oxford, UK) high-performance liquid chromatography (HPLC) system with in-line UV $(280 \mathrm{~nm})$ and radionuclide detector (Flow-Count, LabLogic, UK).

\section{Purification and technetium-99 $\mathrm{m}$ radiolabeling of SER-4 antibody}

Anti-mouse Sn SER-4 antibody was isolated as previously described using the SER-4 hybridoma [12]. Briefly, SER-4 hybridoma cells were grown in Celline CL350 (Integra Biosciences AG, Zissers, Switzerland) according to manufacturer's instructions. Tissue culture media was then harvested and purified on a protein G column followed by dialysis into PBS (Gibco). The SER-4 and the anti-mouse IgG isotype control (AbD Serotec, Oxon, UK) antibodies were directly radiolabelled with ${ }^{99 \mathrm{~m}} \mathrm{Tc}$. Briefly, antibodies were concentrated to $10 \mathrm{mg} / \mathrm{mL}$, using a Vivaspin 20 centrifugal concentrator (Sartorius Stedim, Epsom, UK), and $2 \mathrm{mg}(200 \mu \mathrm{L}, 13 \mathrm{nM})$ was then reduced by a molar excess of 2-mercaptoethanol (2-ME, 2000:1, $2 \mu \mathrm{l}, 26 \mu \mathrm{M}$ ) at room temperature for $30 \mathrm{~min}$. The reduced antibody was purified using a PD-10 desalting column and stored in PBS at $-80{ }^{\circ} \mathrm{C}$ at $5 \mathrm{mg} / \mathrm{mL}$. For antibody radiolabeling, $5 \mu \mathrm{l}$ of a reconstituted MDP kit (Medronate Draximage, Draxis, USA) was added to $0.1 \mathrm{mg}$ 
(20 $\mu \mathrm{L}, 0.67 \mathrm{nM}$ ) of reduced SER-4, followed by the addition of $150 \mathrm{MBq}$ of sodium pertechnetate (provided by Department of Nuclear Medicine at Guys Hospital, UK). Labelling efficiency was measured using instant thin layer chromatography strips (ITLC-SA) (Varian Medical Systems UK, Ltd., Crawley, UK) with a mobile phase of $0.1 \mathrm{M}$ citrate buffer, $\mathrm{pH} 5$ and analysed using a gamma ray TLC scanner (Lablogic, UK). The amount of colloids has not been assessed but that large colloids anyway would have been eliminated by filtration prior to injection.

\section{Stability assay}

Fifty MBq of ${ }^{99 m}$ Tc SER-4 was added to AB type human serum (Sigma) or PBS at 1:4v/v and incubated at $37{ }^{\circ} \mathrm{C}$ for $20 \mathrm{~h}$. Samples were analysed at 0, 3, 6 and $20 \mathrm{~h}$ by HPLC-SEC using a BioSep SEC-300 column (Phenomenex, Macclesfield, UK) with an isocratic mobile phase of $100 \mathrm{mM}$ phosphate buffer $\mathrm{pH} 7.0$ at a flow rate of $1 \mathrm{~mL} / \mathrm{min}$. Stability was calculated as the area under the ${ }^{99 \mathrm{~m}} \mathrm{Tc}-\mathrm{SER}-4$ peak (retention time $=8 \mathrm{~min}$ and $30 \mathrm{~s}$ ) versus the area under the curve of the unbound ${ }^{99 \mathrm{~m}} \mathrm{Tc}$ peak (retention time $=18 \mathrm{~min}$ ).

\section{In vitro ${ }^{99 m}$ Tc SER-4 binding assay}

Of labelled antibody, $0.1 \mu \mathrm{g}$ was added to $0.2 \mu \mathrm{g}$ of recombinant $\mathrm{Sn}-\mathrm{Fc}$ fusion protein $(\mathrm{Sn}-\mathrm{Fc}, 6.7 \mu \mathrm{g} / \mathrm{ml}$ ) and incubated at $37{ }^{\circ} \mathrm{C}$ for $10 \mathrm{~min}$. The proteins were filtered through a $0.2-\mu \mathrm{m}$ syringe filter and binding to $\mathrm{Sn}-\mathrm{Fc}$ was measured by HPLC-SEC and compared to the ${ }^{99 \mathrm{~m}} \mathrm{Tc}-$ IgG isotype binding. Specificity was shown in blocking studies using a 10-fold excess of cold SER-4. No Kd or immunoreactive fraction measurements were performed; as the authors felt that the in vitro competitive binding assay was sufficient to proceed to preclinical studies.

\section{NanoSPECT/CT transplant imaging}

Heterotopic cardiac transplantations were performed on 8 - to 10 -week-old male C57BL/ 6 mice (three groups, $n=5$ for SER4 allogeneic and isotype allogeneic groups) with heart graft from BALB/c mice while syngeneic cardiac transplants ( $n=4$ for SER4 syngeneic group) with heart grafts from C57BL/6 mice as described by Corry et al [30]. All mice were imaged and ex vivo biodistribution was performed. Briefly, superior and inferior vena cava and pulmonary veins of the heart graft were ligated. The donor aorta was then anastomosed to the recipient abdominal aorta and the donor pulmonary artery anastomosed to the inferior vena cava, resulting in a fully vascularised heterotopic transplant. C57BL/6, Sn-deficient $\left(\mathrm{Sn}^{-1-}\right)$ and transplanted mice were anesthetized with inhaled isoflurane gas (VetOne, UK) and $\sim 10 \mu \mathrm{g}(\sim 20 \mathrm{MBq})$ of ${ }^{99 \mathrm{~m}} \mathrm{Tc}-$ SER-4 or ${ }^{99 \mathrm{~m}} \mathrm{Tc}-\mathrm{IgG}$ isotype control was filtered through a $0.2-\mu \mathrm{m}$ syringe filter and administered intravenously. Single-photon emission computed tomography (SPECT)

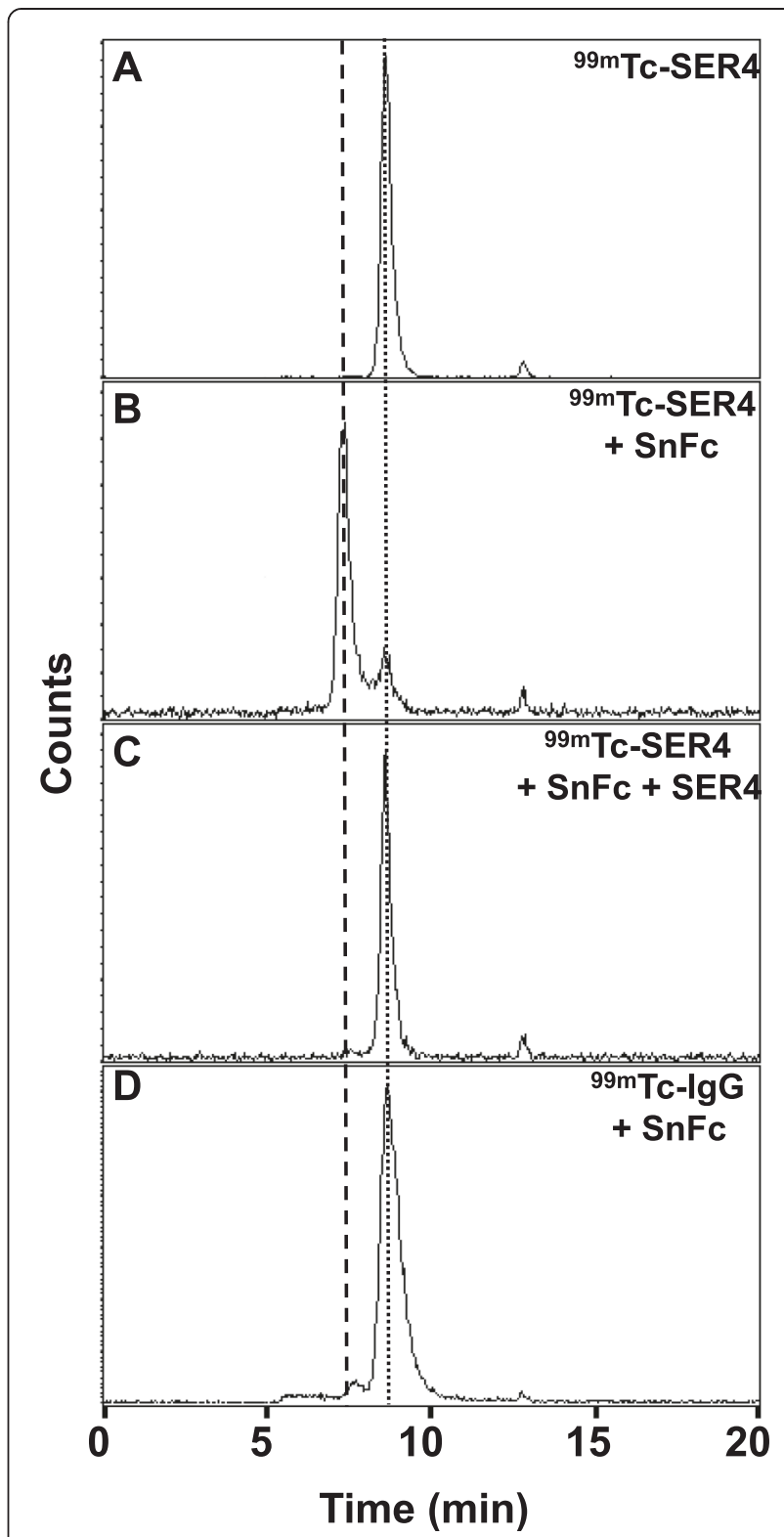

Fig. $1{ }^{99 m}$ TC-SER-4 binds to Sn. Binding studies were performed by incubating ${ }^{99 \mathrm{~m}} \mathrm{Tc}$-SER-4 and Sn-Fc followed by analysis with radio-HPLC size exclusion chromatography. a ${ }^{99 \mathrm{~m}} \mathrm{Tc}$-SER-4 elutes at $8 \mathrm{~min}$ and $35 \mathrm{~s}$. b ${ }^{99 m}$ Tc-SER-4 was added to Sn-Fc and an elution peak at $7 \mathrm{~min}$ and $20 \mathrm{~s}$ was observed corresponding to the ${ }^{99 \mathrm{~m}} \mathrm{Tc}$-SER-4 bound to Sn-FC. c When ${ }^{99 m}$ Tc-SER-4 was added to Sn-Fc protein in the presence of unlabelled SER-4, no binding was observed and only the ${ }^{99 \mathrm{~m}} \mathrm{Tc}-\mathrm{SER}-4$ elution peak was observed. $\mathbf{d}^{99 \mathrm{~m}} \mathrm{Tc}-\mathrm{lg}$ isotype control did not bind to $\mathrm{Sn}-\mathrm{FC}$ with a peak elution time similar to ${ }^{99 \mathrm{~m}} \mathrm{TC}-\mathrm{SER}-4$ of $8 \mathrm{~min}$ and $35 \mathrm{~s}$

images were obtained $3 \mathrm{~h}$ post injection using a nanoSPECT/computed tomography (CT) preclinical scanner (Bioscan Inc., Washington, DC, USA) equipped with four heads, each with 1-mm multipinhole collimator, in helical scanning mode in 24 projections over $30 \mathrm{~min}$. The CT images were obtained with $45 \mathrm{kVP}$ X-ray source, $1000 \mathrm{~ms}$ exposure time in 180 projections over $10 \mathrm{~min}$. Images were 

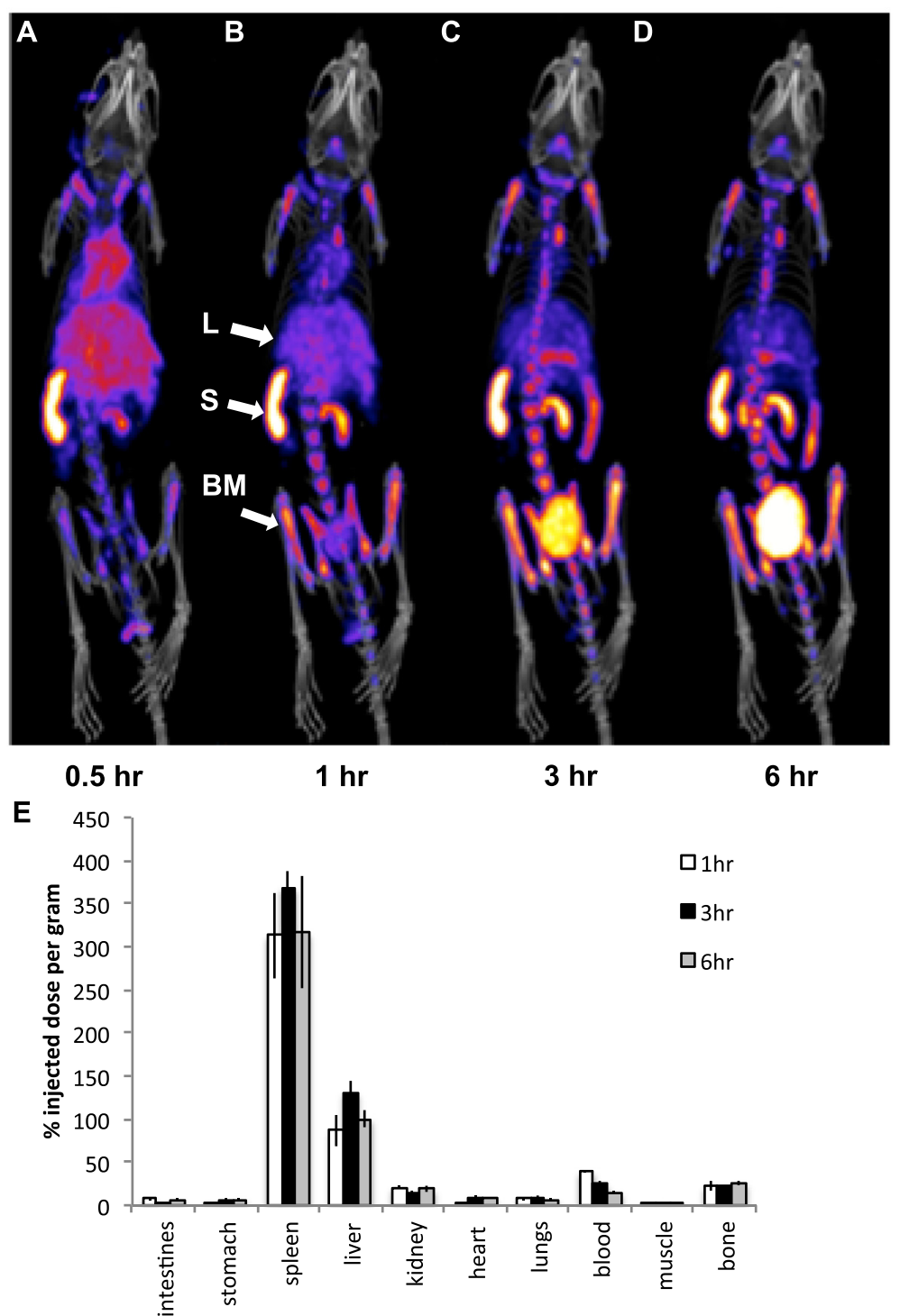

Fig. $2^{99 m}$ Tc-SER-4 NanoSPECT/CT imaging and biodistribution of $\mathrm{Sn}^{+}$macrophages. C57BI/6 wild-type (WT) mice were imaged a $0.5 \mathrm{~h}$, b 1 h, c

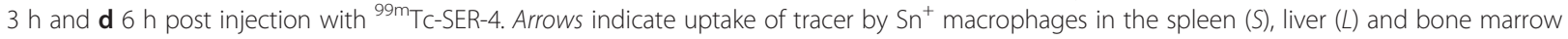
$(B M)$. After imaging, C57BL/6 wild-type (WT) mice were euthanized and tissues explanted, weighed and gamma counted. Maximum intensity projections are shown. e $^{99 \mathrm{~m}} \mathrm{Tc}$-SER-4 biodistributions at 1, 3 and $6 \mathrm{~h}$ post injection were expressed as percentage injected dose per gram of tissue $(\% \mathrm{ID} / \mathrm{g})$. Error bars represent the standard error of the mean of $n=3$

reconstructed in a 256 by 256 matrix using the HiSPECT (Scivis $\mathrm{GmBH}$ ) reconstruction software package and fused using InVivoScope software (Bioscan). Images shown here are maximum intensity projections (MIP). Animals were then euthanized at $4 \mathrm{~h}$ post injection and tissues explanted, weighed and gamma counted on a gamma counter (Wallac, 1282 Compugamma, PerkinElmer, UK). Uptake in each tissue was expressed as percent injected dose per gram of tissue (\% $\mathrm{ID} / \mathrm{g})$. The transplanted heart to blood ratio was calculated by expressing the $\% \mathrm{ID} / \mathrm{g}$ of the transplanted heart divided by \%ID/g in the blood. After imaging, C57BL/ 6 wild-type and $\mathrm{Sn}^{-1-}$ spleens or grafted hearts and spleens from C57BL/6 recipients were removed for histology which was performed as previously described [12].

\section{Immunostaining}

After imaging and biodistribution, frozen tissues were stained for Sn using SER-4 followed by anti-rat-biotin then streptavidinHRP. $\mathrm{Sn}^{+}$macrophages were visualized with Vector NovaRED substrate (red) and sections counterstained with haemotoxylin.

\section{Statistical analysis}

To test for a significant differences between ${ }^{99 \mathrm{~m}} \mathrm{Tc}-\mathrm{SER}-4$ in allogeneic and syngeneic transplants with ${ }^{99 \mathrm{~m}} \mathrm{Tc}-\mathrm{IgG}$ in 

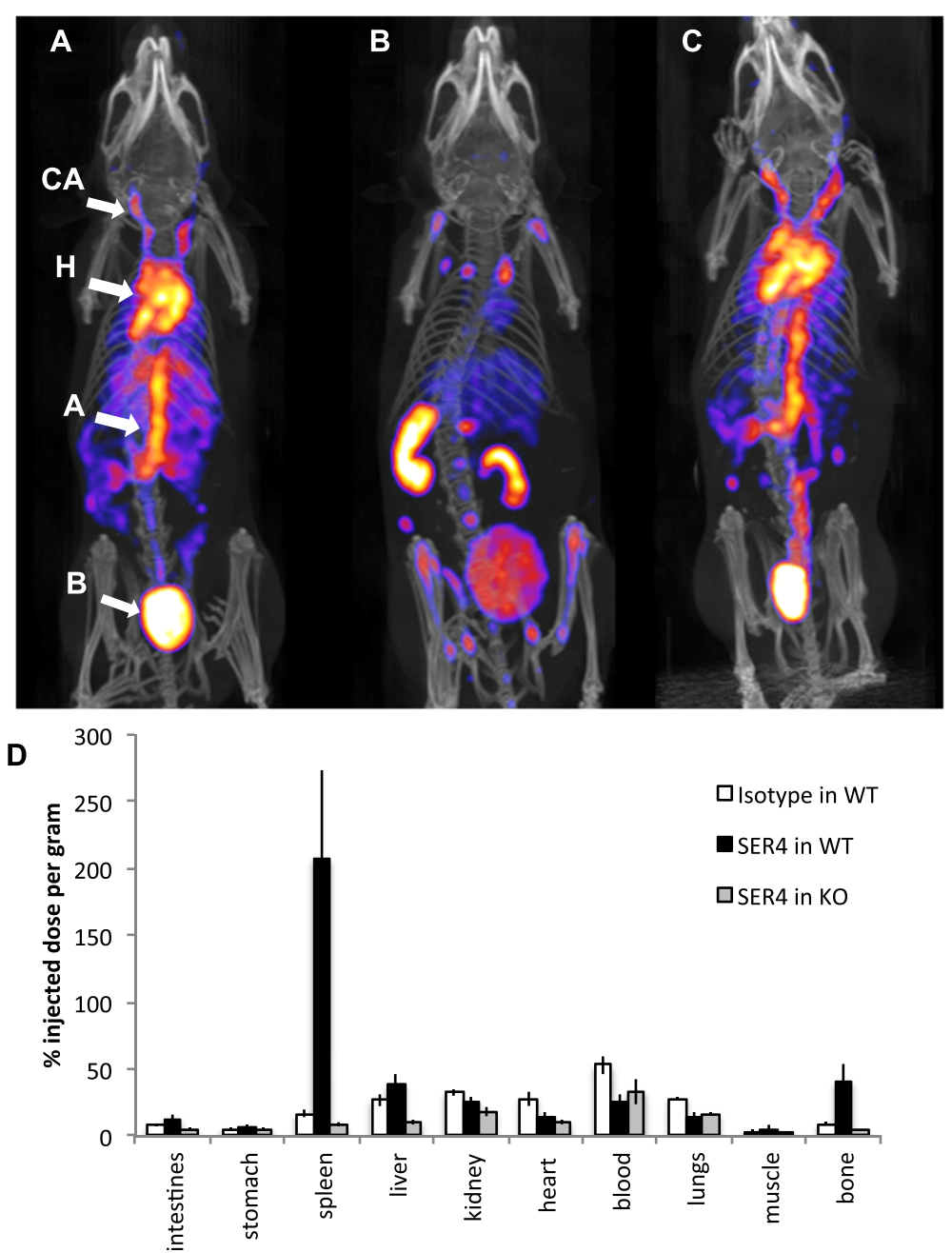

Fig. $3^{99 \mathrm{~m}} \mathrm{Tc}-\mathrm{lgG}$ and ${ }^{99 \mathrm{~m}} \mathrm{Tc}-\mathrm{SER}-4$ nanoSPECT/CT imaging and biodistribution in C57BI/6 wild-type (WT) and $\mathrm{Sn}^{-1-}$ (KO) mice. Imaging was performed $3 \mathrm{~h}$ post injection on C57Bl/6 WT mice with $\mathbf{a}^{99 \mathrm{~m}} \mathrm{TC}-\mathrm{lg}$ G isotype control or $\mathbf{b}^{99 \mathrm{~m}} \mathrm{TC}-\mathrm{SER}-4$ or $\mathbf{c ~ S n}{ }^{-1-}$ mice with ${ }^{99 \mathrm{~m}} \mathrm{TC}-\mathrm{SER}-4$. Arrows indicate signal arising from carotid arteries $(C A)$, heart $(H)$, aorta $(A)$ and bladder $(B)$. Maximum intensity projections are shown. $\mathbf{d}$ Biodistribution of ${ }^{99 \mathrm{~m}} \mathrm{Tc}$-SER-4 in C57BI/6 wild-type, $\mathrm{Sn}^{-1-}$ and ${ }^{99 \mathrm{~m}} \mathrm{Tc}-\mathrm{lgG}$ isotype control in C57BI/6 wild-type mice were expressed as percentage injected dose per gram of tissue $(\% \mathrm{ID} / \mathrm{g})$. Error bars represent the standard error of the mean of $n=5$

allogeneic heart transplants, a one-way ANOVA was first performed; $p$ values of $<0.05$ were considered significant. If the one-way ANOVA was significant, then a post hoc analysis was performed with Student-Newman-Keuls pairwise comparison; $p$ values of $<0.05$ were considered significant.

\section{Results}

${ }^{99 m}$ Tc-SER-4 is stable in serum and binds to sialoadhesin Anti-Sn antibody was produced using the SER-4 hybridoma. SER-4 antibody was reduced with mercaptoethanol and directly radiolabelled with sodium pertechnetate in the presence of methylene-diphosphonate ligand. The radiolabelling efficiency as measured by ITLC was $>99 \%$ with a specific activity of $1.5 \mathrm{MBq} / \mu \mathrm{g}$ of antibody. ${ }^{99 \mathrm{~m}} \mathrm{Tc}-$ SER-4 remained stable in serum for $20 \mathrm{~h}$ with only one radioactive peak observed at a retention time of $8 \mathrm{~min}$ (see Additional file 1). However, when either the ${ }^{99 \mathrm{~m}} \mathrm{Tc}$ SER-4 or ${ }^{99 \mathrm{~m}} \mathrm{Tc}$-IgG was incubated in PBS alone, free pertechnetate was observed after $20 \mathrm{~h}$ (see Additional file 1).

To ensure that the radiolabelling procedure did not adversely affect the ability of SER- 4 to bind to Sn, an in vitro binding assay was developed. Binding was determined by observing a shift in retention time from $8 \mathrm{~min}$ and $35 \mathrm{~s}$ of unbound ${ }^{99 \mathrm{~m}} \mathrm{Tc}-\mathrm{SER}-4$ (Fig. 1a) to ${ }^{99 \mathrm{~m}} \mathrm{Tc}-$ SER- 4 bound to $\mathrm{Sn}-\mathrm{Fc}$ with a retention time of $7 \mathrm{~min}$ and $20 \mathrm{~s}$ (Fig. 1b). The binding of ${ }^{99 \mathrm{~m}}$ Tc-SER- 4 bound to Sn-Fc was inhibited by the addition of unlabelled SER-4 antibody (Fig. 1c). The ${ }^{99 \mathrm{~m}} \mathrm{Tc}-\mathrm{IgG}$ isotype control did not bind to $\mathrm{Sn}-\mathrm{Fc}$ and eluted with a retention time of $8 \mathrm{~min}$ and $30 \mathrm{~s}$ similar to that of unbound ${ }^{99 \mathrm{~m}} \mathrm{Tc}-\mathrm{SER}-4$ (Fig. 1d). 


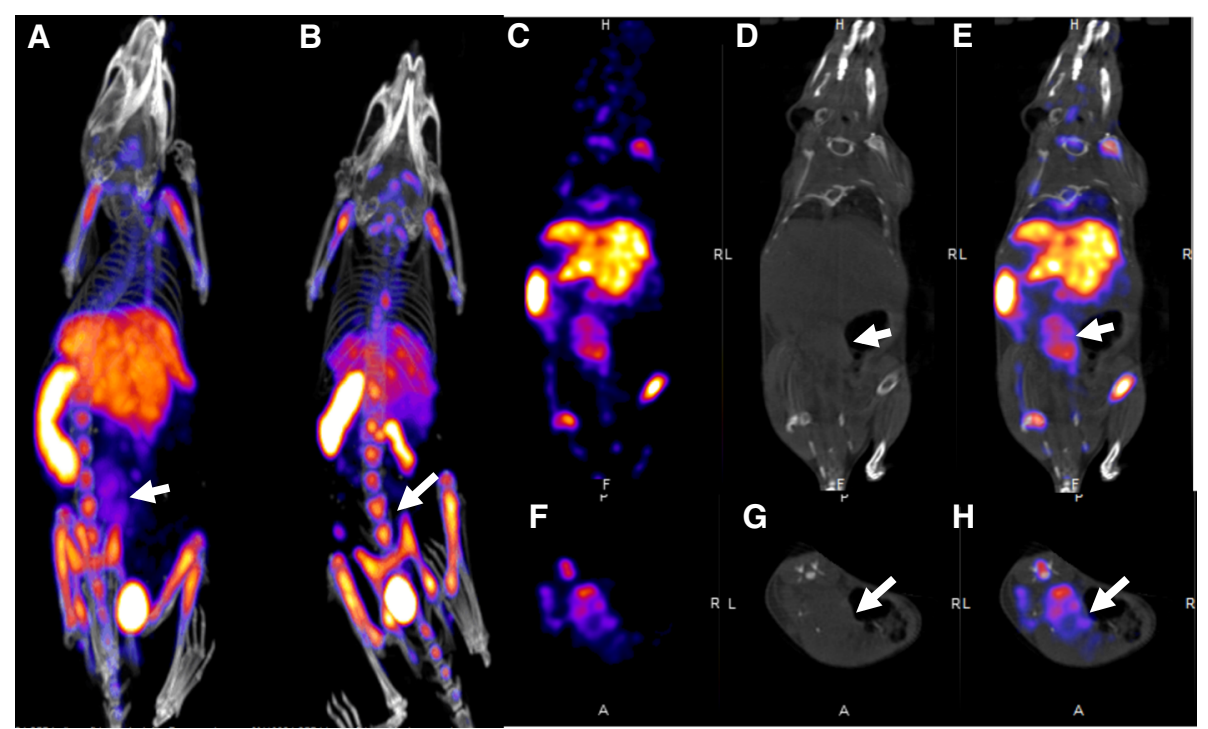

Fig. $4{ }^{99 m}$ TC-SER-4 nanoSPECT/CT imaging of $\mathrm{Sn}^{+}$macrophages in heterotopic cardiac transplant model. Representative maximum intensity projection nanoSPECT/CT images of recipients with either $\mathbf{a}$ allogeneic or $\mathbf{b}$ syngeneic heart graft imaged $3 \mathrm{~h}$ post injection with ${ }^{99 \mathrm{~m}} \mathrm{Tc}-\mathrm{SER}-4$. CT, SPECT and fused images from coronal ( $\mathbf{c}, \mathbf{d}, \mathbf{e}$, respectively) and transversal $(\mathbf{f}, \mathbf{g}, \mathbf{h}$, respectively) planes are also shown. Arrows indicate site of abdominal cardiac transplant with uptake of tracer in allogeneic heart graft that are absent in the syngeneic heart graft model

We did not run an SDS-PAGE to show that the antibody remains intact as the radiolabeled antibody is still able to bind $>99 \%$ to Sn antigen which is completely blocked by cold antigen in a competitive binding assay.

\section{Biodistribution of ${ }^{99 \mathrm{~m}} \mathrm{Tc}$-SER-4 in mice}

C57BL/6 wild-type mice, injected with $20 \mathrm{MBq}$ of ${ }^{99 \mathrm{~m}} \mathrm{Tc}-$ SER-4, were imaged at $0.5,1,3$ and $6 \mathrm{~h}$ post injection (Fig. 2). At $1 \mathrm{~h},{ }^{99 \mathrm{~m}} \mathrm{Tc}-\mathrm{SER}-4$ uptake was already observed in the spleen, liver and bone marrow, which were the expected locations of $\mathrm{Sn}^{+}$macrophages. Additionally, bladder uptake is consistent with previous studies of directly labelled antibodies and is thought to result from transchelation of ${ }^{99 \mathrm{~m}} \mathrm{Tc}$ from disulphides to endogenous cysteine [31]. It has been previously shown that antibodies labelled via the direct labelling method which were then challenged with cysteine led to $\sim 10 \%$ translocation of the Tc- $99 \mathrm{~m}$ to the cysteine [32].

Blood levels of ${ }^{99} \mathrm{~m}$ Tc-SER-4 continued to drop between 3 and $6 \mathrm{~h}$. After imaging, mice were euthanized and standard radioactive biodistribution was performed. The biodistribution results confirmed the non-invasive SPECT/CT images (Fig. 2e). ${ }^{99} \mathrm{~m}$ Tc-SER-4 clears the blood rapidly with $66.7 \% \mathrm{ID} / \mathrm{g}$ in the blood immediately post injection to $15.0 \pm 0.9 \% \mathrm{ID} / \mathrm{g}$ at $6 \mathrm{~h}$ with a clearance half-life in blood of $167 \mathrm{~min}(p=0.0004)$. This is significantly faster blood clearance than expected for most radiolabelled monoclonal antibodies.

As a control, ${ }^{99 \mathrm{~m}} \mathrm{Tc}-\mathrm{SER}-4$ or ${ }^{99 \mathrm{~m}} \mathrm{Tc}-\mathrm{IgG}$ isotype was injected into $\mathrm{Sn}^{-/-}$or C57BL/6 wild-type mice, respectively, and imaged by nanoSPECT/CT at $3 \mathrm{~h}$ post injection (Fig. 3).
Both ${ }^{99 \mathrm{~m}} \mathrm{Tc}-\mathrm{SER}-4$ and ${ }^{99 \mathrm{~m}} \mathrm{Tc}$-IgG remained in the blood of $\mathrm{Sn}^{-1-}$ or wild-type mice, respectively, and reflected the typical biodistribution expected of a $150-\mathrm{kDa}$ radiolabelled monoclonal antibody. Biodistribution results confirmed the SPECT/CT images where the majority of the ${ }^{99 \mathrm{~m}} \mathrm{Tc}-\mathrm{SER}-4$ $(200 \pm 66.0 \% \mathrm{ID} / \mathrm{g})$ was observed in the spleen of wild-type mice. Splenic uptake was lower for ${ }^{99 \mathrm{~m}}$ Tc-SER-4 (8.3 \pm $1.1 \% \mathrm{ID} / \mathrm{g})$ or ${ }^{99 \mathrm{~m}} \mathrm{Tc}-\mathrm{IgG}(16.5 \pm 2.6 \% \mathrm{ID} / \mathrm{g})$ in $\mathrm{Sn}^{-1-}$ or wildtype mice, respectively ( $p=0.0029$ and 0.0025 , respectively). The majority of ${ }^{99} \mathrm{~m} \mathrm{Tc}-\operatorname{IgG} \quad(52.9 \pm 7.0 \% \mathrm{ID} / \mathrm{g})$ in wild-type mice was retained in the blood as compared to ${ }^{99 m}$ Tc-SER-4 in wild-type mice $(26.1 \pm$ $5.4 \% \mathrm{ID} / \mathrm{g})$ (Fig. 3d) $(p=0.002)$. Staining of spleen sections from wild-type mice with SER-4 gave the distinctive stain of $\mathrm{Sn}^{+}$marginal metallophilic macrophages (MMM) in the internal border of the white pulp (Additional file 2). Raw biodistribution data for blood clearance and controls are available in supplemental data (Additional files 3 and 4).

\section{Non-invasive imaging of ${ }^{99 m}$ Tc-SER-4 targets $\mathrm{Sn}^{+}$} macrophages in heterotopic cardiac transplantations Seven days after transplantation of allogeneic or syngeneic heart grafts into the abdomen, recipients underwent nanoSPECT/CT imaging at $3 \mathrm{~h}$ post injection of ${ }^{99 \mathrm{~m}} \mathrm{Tc}-\mathrm{SER}-4$ (Fig. 4). Uptake was observed in the allogeneic graft in the abdomen of recipients (Fig. 4a) but not in recipients receiving a syngeneic graft (Fig. 4b). Again, high levels of ${ }^{99 \mathrm{~m}} \mathrm{Tc}-$ SER-4 were observed in the spleen, liver and bone marrow with only low levels of uptake in non-target tissues. 

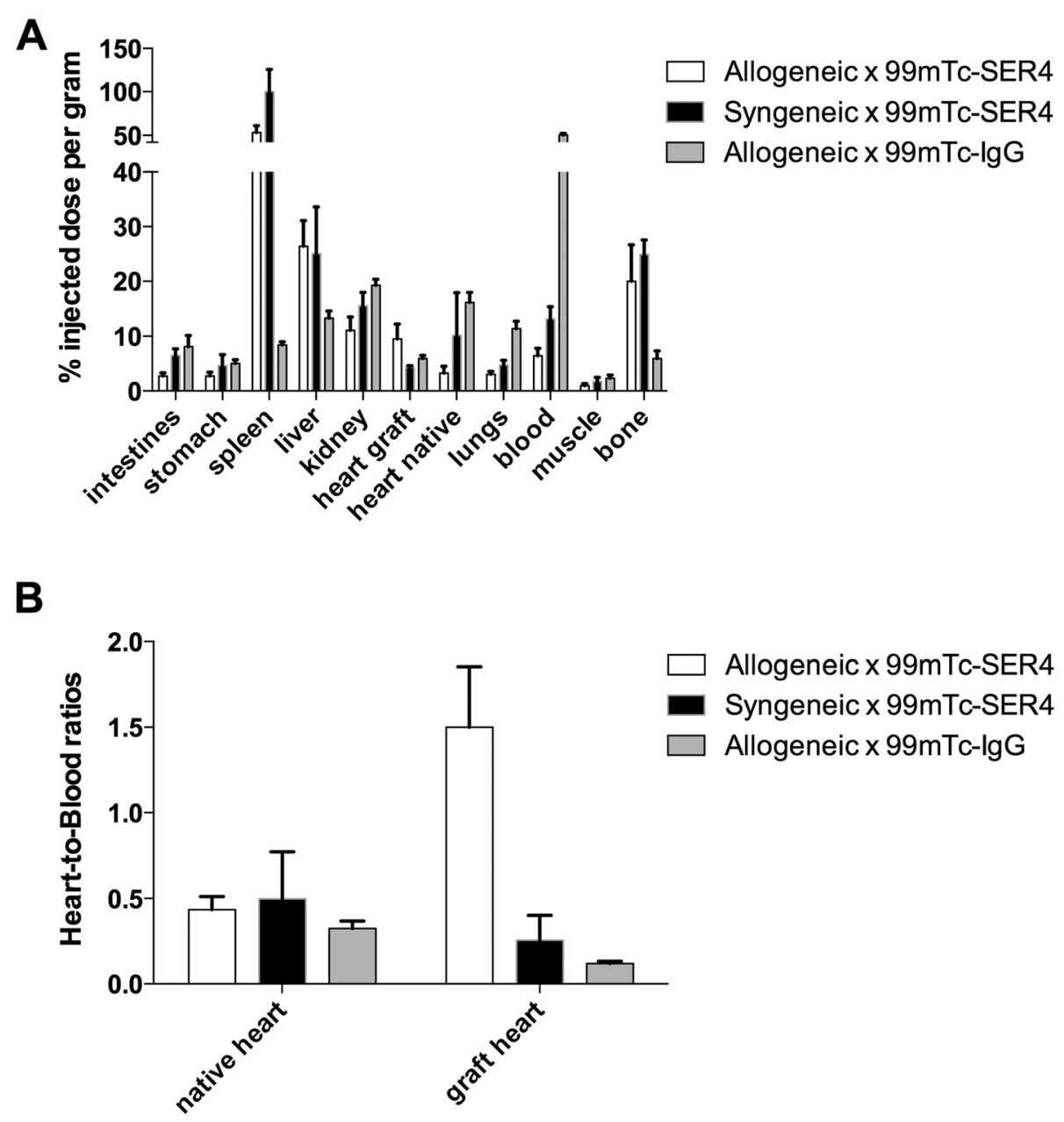

Allogeneic $\times$ 99mTc-SER4

- Syngeneic $\times 99 \mathrm{mTc}-$ SER4

$\square$ Allogeneic x 99mTc-lgG

Fig. 5 Biodistribution of ${ }^{99 \mathrm{~m}} \mathrm{Tc}$-SER-4 in heterotopic cardiac transplant model. a Biodistribution of ${ }^{99 \mathrm{~m}} \mathrm{Tc}$-SER-4 in recipients of allogeneic heart graft, syngeneic heart grafts or allogeneic heart grafts at $4 \mathrm{~h}$ post injection of ${ }^{99 \mathrm{~m}} \mathrm{Tc}-\mathrm{lgG}$ isotype control. $\mathbf{b}$ Transplanted heart to blood ratios for ${ }^{99 \mathrm{~m}} \mathrm{Tc}-\mathrm{SER}-4$ in recipients of allogeneic heart graft, syngeneic heart grafts or allogeneic heart grafts injected with ${ }^{99 \mathrm{~m}} \mathrm{Tc}-\mathrm{lgG}$ isotype control. Error bars represent the standard error of the mean of $n=4-5$

Biodistribution data confirmed a significantly higher uptake of ${ }^{99 \mathrm{~m}}$ Tc-SER-4 in the allogeneic heart grafts $(9.4 \pm 2.7 \% \mathrm{ID} / \mathrm{g})$ compared to syngeneic heart graft $(4.3 .0 \pm 0.3 \% \mathrm{ID} / \mathrm{g})(p=0.0022)$ or in mice which received allogeneic grafts and injected with ${ }^{99 \mathrm{~m}} \mathrm{Tc}$-IgG isotype control $(5.9 \pm 0.6 \% \mathrm{ID} / \mathrm{g})(p=0.0185)$ (Fig. 4). Given that $50.3 \pm 2.2 \% \mathrm{ID} / \mathrm{g}$ of the ${ }^{99 \mathrm{~m}} \mathrm{Tc}$-IgG isotype control was observed at $4 \mathrm{~h}$ in the blood, transplanted heart to blood ratios were also calculated. The heart to blood ratio was significantly higher in recipients with allogeneic grafts receiving ${ }^{99 \mathrm{~m}} \mathrm{Tc}-\mathrm{SER}-4$ as compared to recipients with syngeneic grafts $(p=0.000004)$ or recipients with allogeneic grafts receiving ${ }^{99 \mathrm{~m}} \mathrm{Tc}-\mathrm{IgG}$ isotype $(p=0.000002)$ (Fig. 5). Raw biodistribution data for transplanted mice is available in supplemental data (Additional file 5).

The presence of $\mathrm{Sn}^{+}$macrophages in allogeneic grafts was confirmed in transplants stained with anti-Sn.
Allogeneic grafts showed an abundance of $\mathrm{Sn}^{+}$macrophages while sporadic expression of $\mathrm{Sn}^{+}$macrophages were observed in syngeneic grafts and minor staining in recipient's native hearts (Fig. 6).

\section{Discussion}

We have been able to perform non-invasive imaging specific for macrophages using a radiolabelled antibody. Although much is known about the phenotype of macrophages, these have not been exploited for the development of non-invasive imaging contrast agents. Monoclonal antibodies are being successfully used in immunotherapy of diseases such as cancer where they target antigens such as HER2 using trastuzumab (Herceptin), EGFR with panitumumab (Vectibix) and VEGF-A with bevacizumab (Avastin). Antibodies targeted specifically at immune cells, such as granulocytes, B and T cells, have also been evaluated as diagnostic contrast agents for the 


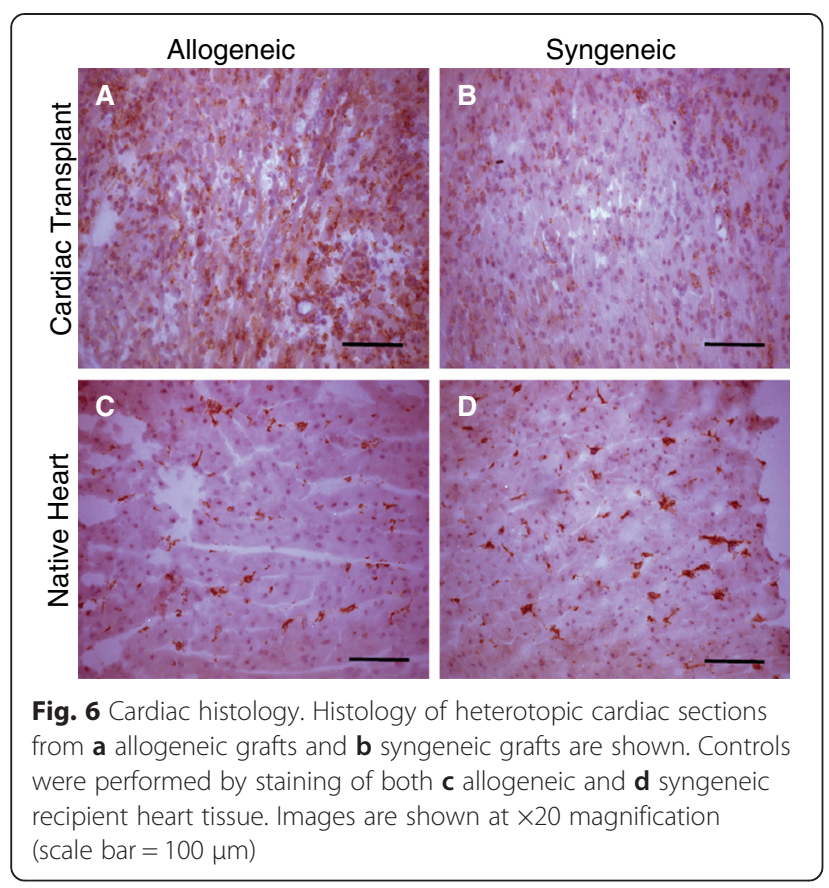

imaging of infection, rheumatoid arthritis and transplant rejection [33]. However, to date, few antibodies are used routinely for diagnostic imaging and many of these have been withdrawn from the market or are still under clinical development [34].

With macrophages being implicated, for better or worse, in many diseases, it is important to be able to target these cells non-invasively to assess prognosis as well as interim assessment of therapeutic interventions. We therefore decided to radiolabel one of the most restricted macrophage surface markers sialoadhesin (CD169). Low expression of Sn was observed in many tissue macrophages (such as in the liver, dermis and lung) but significant expression was observed in macrophages in the secondary lymphoid organs and bone marrow [12]. Sn expression can be upregulated in inflammation via inflammatory mediators such as TNF- $\alpha$ and type I IFN in humans, rats and pigs $[15,35,36]$. SER-4 was radiolabelled with the radioisotope ${ }^{99 \mathrm{~m}} \mathrm{Tc}\left({ }^{99 \mathrm{~m}} \mathrm{Tc}-\mathrm{SER}-4\right)$ and found to be stable in serum but lower stability was observed in PBS after $20 \mathrm{~h}$. We then performed in vivo imaging and biodistribution studies in wild-type mice and in a murine model of heterotopic cardiac transplant. The majority of ${ }^{99 \mathrm{~m}} \mathrm{Tc}-\mathrm{SER}-4$ monoclonal antibodies was cleared from the blood within $3 \mathrm{~h}$ and was located in predominately $\mathrm{Sn}^{+} \mathrm{M}$ tissues such as the spleen, liver and bone marrow. ${ }^{99 \mathrm{~m}}$ Tc-SER-4 uptake was not observed in these tissues in $\mathrm{Sn}^{-1-}$ mice, and ${ }^{99 \mathrm{~m}} \mathrm{Tc}$ IgG isotype control remained in the blood for the duration of the experiment. In the heterotopic cardiac transplants, it was possible to observe ${ }^{99 \mathrm{~m}}$ Tc-SER-4 in allogeneic heart grafts but not in syngeneic heart grafts. This was further quantified by the biodistribution studies which showed significant uptake of ${ }^{99 \mathrm{~m}}$ Tc-SER-4 as compared to radiolabelled isotype control or syngeneic. Histology of the transplanted grafts also demonstrated the presence of $\mathrm{Sn}^{+}$macrophages in the allogeneic heart grafts, and only sporadic expression was observed in the syngeneic or native hearts.

Conventional wisdom tells us that monoclonal antibodies are too large for fast real-time in vivo imaging as they take several days to clear from the blood and also penetrate tissue slowly. However, if one is able to clear non-targeted radiolabelled antibodies quickly from circulation by either providing a fast excretion route via the kidney or liver (which is unlikely for large antibodies) or an endogenous "sink" (identified by biodistribution to be predominantly bone marrow, liver and spleen), then significant targeting of regions of interests may be possible even with low target to background ratios. We have previously also seen evidence of this sink when using antibodies targeting macrophages at $24 \mathrm{~h}$ post injection [8]. To note, we did see non-specific uptake in the kidney using 99mTc-SER-4 biodistribution data which may question its suitability for imaging macrophage infiltration in kidney transplants.

More recent studies have indicated a role for macrophage-mediated rejection as a contributing factor for the progressive decline in graft function, indicating that current immunosuppressive treatment protocols fail to keep at bay the potent effector responses of the adaptive immune system [37]. This imaging technique could equally be used in imaging a model of chronic rejection, and as with acute rejection, the current view is that macrophages promote worse graft outcome through the release of inflammatory mediators and regulation of the cytokine dynamics [38]. Macrophages are a major component of inflammatory infiltrates in rejecting allografts [39]. Macrophages are rapidly recruited to sites of inflammation including allografts where they are responsive to type I interferons, while at the same time potent producers of pro-inflammatory cytokines such as IL-1, IL-6 and TNF-beta [40]. The early infiltration of macrophages post organ transplantation has been observed in biopsies demonstrating acute cellular rejection as well as in acute humoral rejection and has been shown to be associated with relatively poor allograft survival [41]. More recently, increased monocyte expression of sialoadhesin was observed during acute cellular rejection after intestine transplantation in children [42].

\section{Conclusions}

Radiolabelled SER4 has demonstrated the ability to specifically image non-invasively pro-inflammatory macrophage infiltrate into rejected grafts, which may provide an important additional tool for the monitoring of transplanted organs. 


\section{Additional files}

Additional file 1: Figure S1. Serum stability of ${ }^{99 \mathrm{~m} T C-S E R-4 .}{ }^{99 \mathrm{~m}} \mathrm{Tc}$-SER-4 was incubated in the presence of phosphate-buffered saline (B) or serum (C) for $20 \mathrm{~h}$ at $37^{\circ} \mathrm{C}$ then injected into SEC radioHPLC system. Percentage bound was assessed by comparison of bound activity (integral of $8 \mathrm{~min}$ and $25 \mathrm{~s}$ peak) to that of free activity (integral of $17 \mathrm{~min}$ and $45 \mathrm{~s}$ peak). ${ }^{99 \mathrm{~m}} \mathrm{TcO} 4$ is included as a control (A). (PDF $73 \mathrm{~kb}$ )

Additional file 2: Figure S2. Spleen sections from wild-type animals stained with SER-4 and counterstained with haematoxylin. White arrow denotes white pulp, black arrow denotes red pulp and black arrowhead denotes marginal metallophilic macrophages. (PDF 798 kb)

Additional file 3: Table S1. Timecourse biodistribution of 99mTc-SER-4 in wild-type mice. Biodistribution of ${ }^{99 \mathrm{~m}} \mathrm{Tc}$-SER-4 in wild-type mice at 1, 3 and $6 \mathrm{~h}$ post injection. Data expressed as percentage injected dose per gram of tissue (\%/D/g). (PDF $63 \mathrm{~kb})$

Additional file 4: Table S2. Biodistribution of ${ }^{99 \mathrm{~m} T c-l g G}$ and ${ }^{99 m} \mathrm{Tc}$ TER-4 in C57Bl/6 wild-type (WT) and $\mathrm{Sn}^{-1}$ (KO) mice. Biodistribution of ${ }^{99 \mathrm{~m}} \mathrm{Tc}-\mathrm{lgG}$ isotype control in C57BI/6 wild-type mice (WT $\times$ Isotype) ${ }^{99 m}$ Tc-SER-4 in C57BI/6 wild-type (WT $\times{ }^{99 m} \mathrm{Tc}$-SER4) and $\mathrm{Sn}^{-1-}$ mice $(\mathrm{Sn} \mathrm{KO} \times 99 \mathrm{mTCSER} 4)$ were expressed as percentage injected dose per gram of tissue (\%lD/g).

(PDF $70 \mathrm{~kb})$

Additional file 5: Table S3. Biodistribution of 99mTC-SER-4 in heterotopic cardiac transplant model. Biodistribution of ${ }^{99 \mathrm{~m}} \mathrm{Tc}$-SER-4 in recipients of allogeneic heart graft (mouse 1-5), syngeneic heart grafts (mouse 6-9),

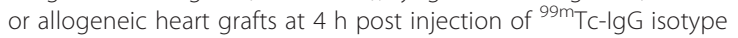
control (mouse 10-14). Data expressed as percentage injected dose per gram of tissue (\%ID/g). (PDF $67 \mathrm{~kb})$

\section{Abbreviations}

mAb: monoclonal antibody; MRI: magnetic resonance imaging; Sn: sialoadhesin; SPECT: single-photon emission computed tomography; SPIO: superparamagnetic iron oxide.

\section{Competing interests}

The authors declare that they have no competing interests.

\section{Authors' contributions}

AO designed the study, performed in vitro assays, prepared radiotracers and executed imaging studies. KB, LM and WW performed cardiac transplants. AW and JC provided technical assistance. GM drafted manuscripts and participated in study design. ST drafted manuscripts. PC revised manuscripts and provided technical assistance. All authors read and approved the final manuscript.

\section{Acknowledgements}

AO was supported by a Lord Harris studentship and would like to recognize Dr James Blundell's assistance in statistical analysis of the data herein and Drs Levente Mezsaros and Jennifer Williams for their assistance during imaging studies.

\section{Compliance with ethical standards}

Disclosure of potential conflicts of interest

Funding: This research was supported by the Centre of Excellence in Medical Engineering funded by the Wellcome Trust and EPSRC under grant number WT088641/Z/09/Z, the King's College London and UCL Comprehensive Cancer Imaging Centre funded by CRUK and EPSRC in association with the MRC Centre for Transplantation and DoH (England), by the National Institute for Health Research (NIHR) Biomedical Research Centre based at Guy's and St Thomas' NHS Foundation Trust and King's College London. PET and SPECT scanning equipment at $\mathrm{KCL}$ was funded by an equipment grant from the Wellcome Trust under the grant number WT 084052/Z/07/Z. The views expressed are those of the authors and not necessarily those of the NHS, the $\mathrm{NIHR}$ or the Department of Health.

Research involving human participants and/or animals a. Statement of human rights

This article does not contain any studies with human participants performed by any of the authors.

b. Statement on the welfare of animals
Ethical approval: "All applicable international, national, and/or institutional guidelines for the care and use of animals were followed."

Informed consent

N/A

\section{Author details}

${ }^{1}$ Department of Imaging Chemistry and Biology, Division of Imaging Sciences and Biomedical Engineering, King's College London, St. Thomas' Hospital, London SE1 7EH, UK. 'Division of Medical Sciences, University of Oxford, John Radcliffe Hospital, Oxford OX3 9DU, UK. ${ }^{3}$ MRC Centre for Transplantation, King's College London, Guy's Hospital, London, UK. ${ }^{4}$ Pediatric Storage Disorders Laboratory, Department of Neuroscience and Centre for the Cellular Basis of Behaviour, King's College London, London, UK. ${ }^{5}$ Division of Cell Signalling and Immunology, College of Life Sciences, University of Dundee, Dundee, UK.

Received: 10 July 2015 Accepted: 16 November 2015 Published online: 26 November 2015

\section{References}

1. Mosser DM, Edwards JP. Exploring the full spectrum of macrophage activation. Nat Rev Immunol. 2008;8:958-69.

2. Pollard JW. Trophic macrophages in development and disease. Nat Rev Immunol. 2009;9:259-70.

3. Taylor PR, Martinez-Pomares L, Stacey M, Lin HH, Brown GD, Gordon S. Macrophage receptors and immune recognition. Annu Rev Immunol. 2005; 23:901-44.

4. Zola H, Swart B, Nicholson I, Voss E. Leukocyte and stromal cell molecules: the CD markers. Hoboken: Wiley-Liss; 2007.

5. Beckmann N, Cannet C, Babin AL, Ble FX, Zurbruegg S, Kneuer R, et al. In vivo visualization of macrophage infiltration and activity in inflammation using magnetic resonance imaging. Rev Nanomed Nanobiotechnol. 2009;1: 272-98.

6. Berry DJ, Ma Y, Ballinger JR, Tavare R, Koers A, Sunassee $K$, et al. Efficient bifunctional gallium-68 chelators for positron emission tomography: tris(hydroxypyridinone) ligands. Chem Commun. 2011;47:7068-70.

7. Van Hemert FJ, Voermans C, Van Eck-Smit BL, Bennink RJ. Labeling monocytes for imaging chronic inflammation. J Nucl Med Mol Imaging. 2009;53:78-88.

8. Terry SY, Boerman OC, Gerrits D, Franssen GM, Metselaar JM, Lehmann S, et al. 111/n-anti-F4/80-A3-1 antibody: a novel tracer to image macrophages. Eur J Nucl Med Mol Imaging. 2015;42:1430-8.

9. Eichendorff S, Svendsen P, Bender D, Keiding S, Christensen El, Deleuran B, et al. Biodistribution and PET imaging of a novel [68Ga]-anti-CD163-antibody conjugate in rats with collagen-induced arthritis and in controls. Mol Imaging Biol. 2015;17:87-93

10. Sun X, Gao D, Gao L, Zhang C, Yu X, Jia B, et al. Molecular imaging of tumorinfiltrating macrophages in a preclinical mouse model of breast cancer. Theranostics. 2015;5:597-608.

11. Boutin H, Murray K, Pradillo J, Maroy R, Smigova A, Gerhard A, et al. 18 F-GE-180: a novel TSPO radiotracer compared to 11C-R-PK11195 in a preclinical model of stroke. Eur J Nucl Med Mol Imaging. 2015;42:503-11.

12. Crocker $P R$, Gordon $S$. Mouse macrophage hemagglutinin (sheep erythrocyte receptor) with specificity for sialylated glycoconjugates characterized by a monoclonal antibody. J Exp Med. 1989;169:1333-46.

13. Klaas $M$, Crocker PR. Sialoadhesin in recognition of self and non-self. Semin Immunopathol. 2012;34:353-64

14. O'Neill AS, van den Berg TK, Mullen GE. Sialoadhesin-a macrophage-restricted marker of immunoregulation and inflammation. Immunology. 2013;138:198-207.

15. Hartnell A, Steel J, Turley H, Jones M, Jackson DG, Crocker PR. Characterization of human sialoadhesin, a sialic acid binding receptor expressed by resident and inflammatory macrophage populations. Blood. 2001;97:288-96.

16. Ikezumi Y, Suzuki T, Hayafuji S, Okubo S, Nikolic-Paterson DJ, Kawachi H, et al. The sialoadhesin (CD169) expressing a macrophage subset in human proliferative glomerulonephritis. Nephrol Dial Transplant. 2005;20:2704-13.

17. Nath D, Hartnell A, Happerfield L, Miles DW, Burchell J, Taylor-Papadimitriou J, et al. Macrophage-tumour cell interactions: identification of MUC1 on breast cancer cells as a potential counter-receptor for the macrophage-restricted receptor, sialoadhesin. Immunology. 1999;98:213-9. 
18. Martinez-Pomares L, Gordon S. CD169+ macrophages at the crossroads of antigen presentation. Trends Immunol. 2012;33:66-70.

19. Asano K, Nabeyama A, Miyake Y, Qiu CH, Kurita A, Tomura M, et al. CD169positive macrophages dominate antitumor immunity by crosspresenting dead cell-associated antigens. Immunity. 2011;34:85-95.

20. Phan TG, Green JA, Gray EE, Xu Y, Cyster JG. Immune complex relay by subcapsular sinus macrophages and noncognate B cells drives antibody affinity maturation. Nat Immunol. 2009:10:786-93.

21. Barral P, Polzella P, Bruckbauer A, van Rooijen N, Besra GS, Cerundolo V, et al. CD169(+) macrophages present lipid antigens to mediate early activation of iNKT cells in lymph nodes. Nat Immunol. 2010;11:303-12.

22. Backer $R$, Schwandt $T$, Greuter $M$, Oosting $M$, Jungerkes $F$, Tuting $T$, et al. Effective collaboration between marginal metallophilic macrophages and CD8+ dendritic cells in the generation of cytotoxic T cells. Proc Natl Acad Sci U S A. 2010;107:216-21.

23. Poderoso T, Martinez P, Alvarez B, Handler A, Moreno S, Alonso F, et al. Delivery of antigen to sialoadhesin or CD163 improves the specific immune response in pigs. Vaccine. 2011;29:4813-20.

24. Ip CW, Kroner A, Crocker PR, Nave KA, Martini R. Sialoadhesin deficiency ameliorates myelin degeneration and axonopathic changes in the CNS of PLP overexpressing mice. Neurobiol Dis. 2007;25:105-11.

25. Kobsar I, Oetke C, Kroner A, Wessig C, Crocker P, Martini R. Attenuated demyelination in the absence of the macrophage-restricted adhesion molecule sialoadhesin (Siglec-1) in mice heterozygously deficient in PO. Mol Cell Neurosci. 2006:31:685-91.

26. Wu C, Rauch U, Korpos E, Song J, Loser K, Crocker PR, et al. Sialoadhesin-positive macrophages bind regulatory $T$ cells, negatively controlling their expansion and autoimmune disease progression. J Immunol. 2009;182:6508-16.

27. Xiong YS, Zhou YH, Rong GH, Wu WL, Liang Y, Yang ZX, et al. Siglec-1 on monocytes is a potential risk marker for monitoring disease severity in coronary artery disease. Clin Biochem. 2009;42:1057-63.

28. Hariharan S, Johnson CP, Bresnahan BA, Taranto SE, Mclntosh MJ, Stablein D. Improved graft survival after renal transplantation in the United States, 1988 to 1996. N Engl J Med. 2000;342:605-12.

29. Badar A, DeFreitas S, McDonnell JM, Yahya N, Thakor D, Razavi R, et al. Recombinant complement receptor 2 radiolabeled with [99mTc(CO)3]+: a potential new radiopharmaceutical for imaging activated complement. PLoS One. 2011;6, e18275.

30. Corry RJ, Winn HJ, Russell PS. Heart transplantation in congenic strains of mice. Transplant Proc. 1973;5:733-5.

31. Hnatowich DJ, Mardirossian G, Rusckowski M, Fogarasi M, Virzi F, Winnard Jr P. Directly and indirectly technetium-99 m-labeled antibodies-a comparison of in vitro and animal in vivo properties. J Nucl Med. 1993;34:109-19.

32. Sykes TR, Woo TK, Baum RP, Qi P, Noujaim AA. Direct labeling of monoclonal antibodies with technetium-99 m by photoactivation. J Nucl Med. 1995;36:1913-22.

33. Malviya G, Galli F, Sonni I, Pacilio M, Signore A. Targeting T and B lymphocytes with radiolabelled antibodies for diagnostic and therapeutic applications. J Nucl Med Mol Imaging. 2010;54:654-76.

34. Goldsmith SJ, Signore A. An overview of the diagnostic and therapeutic use of monoclonal antibodies in medicine. J Nucl Med Mol Imaging. 2010;54: $574-81$.

35. van den Berg TK, van Die I, de Lavalette CR, Dopp EA, Smit LD, van der Meide $\mathrm{PH}$, et al. Regulation of sialoadhesin expression on rat macrophages. Induction by glucocorticoids and enhancement by IFN-beta, IFN-gamma, IL-4, and lipopolysaccharide. J Immunol. 1996;157:3130-8.

36. Delputte PL, Van Breedam W, Delrue I, Oetke C, Crocker PR, Nauwynck HJ. Porcine arterivirus attachment to the macrophage-specific receptor sialoadhesin is dependent on the sialic acid-binding activity of the N-terminal immunoglobulin domain of sialoadhesin. J Virol. 2007;81:9546-50.

37. Li XC. The significance of non-T-cell pathways in graft rejection: implications for transplant tolerance. Transplantation. 2010:90:1043-7.

38. Salehi S, Reed EF. The divergent roles of macrophages in solid organ transplantation. Curr Opin Organ Transplant. 2015;20:446-53.

39. Langrehr JM, White DA, Hoffman RA, Simmons RL. Macrophages produce nitric oxide at allograft sites. Ann Surg. 1993;218:159-66.

40. Kimura A, Naka T, Kishimoto T. IL-6-dependent and -independent pathways in the development of interleukin 17-producing T helper cells. Proc Natl Acad Sci U S A. 2007;104:12099-104.
41. Pilmore HL, Painter DM, Bishop GA, McCaughan GW, Eris JM. Early up-regulation of macrophages and myofibroblasts: a new marker for development of chronic renal allograft rejection. Transplantation. 2000;69:2658-62.

42. Ashokkumar C, Gabriellan A, Ningappa M, Mazariegos G, Sun Q, Sindhi R. Increased monocyte expression of sialoadhesin during acute cellular rejection and other enteritides after intestine transplantation in children. Transplantation. 2012;93:561-4.

\section{Submit your manuscript to a SpringerOpen ${ }^{\odot}$ journal and benefit from:}

- Convenient online submission

- Rigorous peer review

- Immediate publication on acceptance

- Open access: articles freely available online

- High visibility within the field

- Retaining the copyright to your article

Submit your next manuscript at $\gg$ springeropen.com 